\title{
Anesthesia Experience in a Patient with Myotonia Congenita
}

\author{
Konjenital Miyotonili Bir Hastadaki Anestezi Deneyimimiz
}

\section{(D) Yeşim Cokay Abut, (D) Serkan Şimşek, (D) Seher Köse, (DŞenay Kirgezen, (D Kübra Bolat, (D) Veysel Erden}

University of Health Sciences, İstanbul Training and Research Hospital, Clinic of Anesthesia and Reanimation, İstanbul, Turkey

\section{Abstract}

Myotonia congenita (MC) was first described as a skeletal muscle disorder by Thomsen in 1876. As a result of the mutation of the chloride channel gene (CLCN1), which is on the $17^{\text {th }}$ chromosome, patients suffer from muscle contractility and fatigue. Malignant hyperthermia may occur in these patients in anesthesia. We presented our anesthesia experience in a patient who suffers from $\mathrm{MC}$ in this article.

Keywords: Myotonia congenita, malignant hyperthermia, anesthesia

\section{Öz}

Myotoni konjenita (MC), Thomsen tarafından, 1876 yılında, iskelet kaslarında ortaya çıkan bir hastalık olarak tanımlanmıştır. On yedinci kromozomda yer alan klor kanalı geninin (CLCN1) bir mutasyonu sonucunda, hastalarda kas kontraksiyonları ve yorgunluk ortaya çıkar. $\mathrm{Bu}$ hastalarda anestezi altında malin hipertermi gelişebilir. Aşağıda bir MC hastasıyla ilgili olarak yaşadığımız anestezi deneyimini paylaşmak istiyoruz.

Anahtar kelimeler: Myotoni konjenita, malin hipertermi, anestezi

\section{Introduction}

Myotonia congenita (MC) was first described as a skeletal muscle disorder by Thomsen in 1876. As a result of the mutation of the chloride channel gene (CLCN1), which is on the $17^{\text {th }}$ chromosome, patients suffer from muscle contractility and fatigue. Autosomal dominance and autosomal recessive heredity may present in this disease $(1,2)$ The prevalence of MC is $1 / 100000$ all over the world (3). In this disease, muscle contraction, hypertrophy and contracture are present without muscle weakness. Dysphagia, aspiration and cardiomyopathy are frequent symptoms. The most important complication is malignant hyperthermia in this patients.

We presented our anesthesia experience in a patient who suffer from MC in this article.

\section{Case Report}

A 54-year-old male patient (American Society Anesthesiologists 2, body mass index: 24) with right upper quadrant abdominal pain, nausea and vomiting was admitted to a general surgery clinic for cholecystectomy. The patient was diagnosed with MC at the age of 16 with complaints of fatigue. Since then he was followed up by neurology department with oral treatment of carbamazepin $200 \mathrm{mg}$ per day. There was no family history about MC or malignant hyperthermia and no previous anesthetic exposure. There were no symptoms of muscle weakness or rigidity in his physical exam, but intubation difficulty signs (Mallampati 3, oral cavity opening less than $2.5 \mathrm{~cm}$ ) were present. Thyromenthal and stermomenthal distance normal, head extantion is not restricted. Neurology department recommended that anesthesiology department must be prepared for

Address for Correspondence: Yesim Cokay Abut, University of Health Sciences, İstanbul Training and Research Hospital, Clinic of Anesthesia and

E-mail: yesimabut2000@yahoo.com ORCID ID: orcid.org/0000-0001-8763-605X Received: 01.02.2019 Accepted: 02.04.2019

Cite this article as: Cokay Abut Y, Şimşek S, Köse S, Şenay Kırgezen, Bolat K, Erden V. Anesthesia Experience in a Patient with Myotonia Congenita. Bagcilar Med Bull 2019;4(2):53-55

() Copyright 2019 by the Health Sciences University, Bagcilar Training and Research Hospital Bagcilar Medical Bulletin published by Galenos Publishing House. 
malign hyperthermia during anesthesia. They pointed out that all precautions related with malign hyperthermia (especially dantrolene sodium) should be provided and anesthesiology department should be alert that postoperative recovery period of the patient could be much longer than the normal patients.

Before the operation, anesthesia machine was flushed with $15 / \mathrm{L} / \mathrm{min}\left(\mathrm{O}_{2}\right)$ about 20 minute. Respiratory circuit, soda lime and filter were changed. Any premedication was not applied to the patient. Electrocardiogram (ECG), noninvasive blood pressure, $\left(\mathrm{SpO}_{2}\right)$, $\left(\mathrm{EtCO}_{2}\right)$ and esophageal temperature were monitorized. In the induction period, $200 \mathrm{mg}$ propofol and $200 \mathrm{mcg}$ fentanyl were injected to the patient. He was intubated with video-laryngoscope C-mac D blade and intubation stylet without administering any muscle relaxant drug. Maintenance of anesthesia was provided with total intravenous anesthesia (TIVA) (propofol and remifentanil), and patient was ventilated with $6 \mathrm{~L} / \mathrm{min}$ $50 \%$ oxygen/air mixture. During the operation, $1000 \mathrm{~mL}$ isotonic saline was infused.

In the operation period patient vital parameters and hemodynamic status were stable and esophageal temperature was $35.9-36.2{ }^{\circ} \mathrm{C}$, $\left(\mathrm{ETCO}_{2}\right)$ values were $32-35$ $\mathrm{mmHg}$. During the operation blood gas analysis values were within normal limits (Ph: 7.4, $\mathrm{PCO}_{2}$ : 38, P02: 184, lactate: $0,8, \mathrm{~K}: 3,4)$. For the postoperative pain control, tramadol $\mathrm{HCl} 100 \mathrm{mg}$ was administered.

Operation was finished after 90 minutes. But spontanous ventilation was not achieved. The patient was transferred to the intensive care unit (ICU), because of the prolonged recovery time. After 3 hours in the ICU, patient was selfextubated. The patient was discharged to the general surgery ward without any sequel and with full recovery on the $2^{\text {nd }}$ day of the operation.

\section{Discussion}

MC first described by A. J. Thomsen in 1876 in his own family. Therefore, this autosomal dominate myotonia is named as Thomsen. It begins at the childhood and affects the upper extremities. Temporary muscle rigidity diminishes with rest. The prognosis of this disease is good (4).

In our patient similar symptoms (fatigue without muscle weakness, muscle rigidity which diminishes with rest and responds medical treatment) were present. The disorder had been diagnosed at 16 years old and had responded well to drug therapy with carbamazepine. The efficacy of carbamazepine treatment in the literature has been explained by membrane stabilization by reducing posttetanic potentials as to be in our patient (5).

In another type of myotonia is named by Becker, lower extremities are mainly affected. In this form, symptoms are more severe than to be in the Thomsen type (6).

In pulmonary and neuromuscular diseases such as MCs, regional anesthesia should be preferred instead of general anesthesia. If general anesthesia is performed, short-acting drugs such as propofol and remifentanil can be used as to be in our patient (7).

It should also be kept in mind that masseter muscle spasm may develop during the induction of anesthesia in myotonic diseases (8).

When the inhalation anesthetics were used, shivering may occur, and myotonia may increase (9).We administered TIVA with remifentanil and propofol, instead of inhalation anesthetics. In our anesthetic plan, we did not prefer to use muscle relaxants. We chose intravenous anesthetic drugs, especially narcotic analgesics for intubation and maintenance of anesthesia, because shivering might not be observed with opioid analgesic agents.

This type neuromuscular diseases can cause malign hyperthermia during anesthesia because of increased muscle activity (10). We took some precautions against possibility of malign hyperthermia (11). We kept ready dantrolene sodium in the operation theatre. With the help of Medical Crisis Center in İstanbul, we achieved the drug from another Training and Research Hospital. For our safety precautions, we flushed the anesthetic machine before the operation, we changed the ventilation circuits, soda lime and filter, and we chose the anesthetic drugs that did not trigger malign hyperthermia.

Because, pain could be induced muscle rigidity, postoperative pain control is very important in these patients $(12,13)$. Therefore, we administered tramadol intravenous intraoperative and postoperative period to our patient.

It was reported in the literature that cold environment, tremors, hyperkalemia, and mechanical or electrical stimulation may trigger myotonia in these patients, and acidosis may occur $(14,15,16,17)$. For this reason, arterial blood gas analysis was followed and normothermia was provided by heat monitoring in our patient. Thanks to these precautions, acidic acidosis was not observed.

Prior to anesthesia of patients with $\mathrm{CM}$, preoperative evaluation, laboratory tests, relevant consultations, 
anesthetic drugs to be used, normothermia and ICU follow-up in postoperative period are also important. If anesthesiologyst can't obtain dantrolene natrium, TIVA could be a safe solution with the precautions that were present above.

\section{Ethics}

Informed Consent: Informed consent from patients.

Peer-review: Internally and externally peer-reviewed.

\section{Authorship Contributions}

Concept: Y.C.A., Design: S.Ş., Y.C.A., Ş.K. Data Collection or Processing: S.Ş., S.K., K.B., Analysis or Interpretation: V.E., Literature Search: S.Ş., S.K., K.B., Writing: S.Ş., Y.C.A., Ş.K.

Conflict of Interest: No conflict of interest was declared by the authors.

Financial Disclosure: The authors declared that this study received no financial support.

\section{References}

1. Russel SH, Hirsch NP. Anaesthesia and myotonia. Br J Anaesth 1994;72:210-216.

2. Jurkat-Rott K, Lehmann-Horn F. Human muscle voltagegated ion channels and hereditary disease. Curr Opin Pharmacol 2001;1:280287.

3. Sun C, Tranebjaerg L, Torbergsen T, Holmgren G, van Ghelue M. Spectrum of CLCN1 mutations in patients with myotonia congenita in Northern Scandinavia. Eur J Hum Genet 2001;9:903909.

4. Parness J, Bandschapp O, Girard T. The Myotonias and Susceptibility to Malignant Hyperthermia. Anesth Analg 2009;109:1054-1064.
5. Savitha MR, Krishnamurthy B, Hyderi A, Farhan-Ul-Haque, Ramachandra NB. Myotonia congenita--a successful response to carbamazepine. Ind J Pediatr 2006;73:431-433.

6. Heatwole CR, Moxley RT. The nondystrophic myotonias. Neurotherapeutics 2007;4:238-251.

7. England DE: Mutant sodium channels, myotonia and propofol, Muscle Nerve 2001;24:713-715.

8. Looi I, Bakar A, Lim CH, Khoo TH, Samuel PE. Anaesthetists' nightmare: masseter spasm after induction in an undiagnosed case of myotonia congenita. Med J Malaysia 2008;63:423-425.

9. Vaughan MS, Vaughan RW, Cork RC. Hypothermia in adults: relationship of age, anesthesia and shivering to rewarming. Anesth Analg 1981;60:746-751.

10. Heimann-Patterson T, Martino C, Rosenberg H, Fletcher JE, Tahmoush AJ. Malignant hyperthermia in myotonia congenita. Neurology 1988;38:810-812.

11. Marsh S, Ross N, Pittard A. Neuromuscular disorders and anaesthesia. Part 1: Generic Anaesthetic Management Continuing Education in Anaesthesia, Critical Care and Pain 2011;11:115-118.

12. Conravey A, Santana-Gould L. Myotonia congenita and myotonic dystrophy: surveillance and management. Curr Treat Options Neurol 2010;12:1628.

13. Cohen IT, Kaplan R. Repeat episodes of severe muscle rigidity in a child receiving sevoflurane. Paediatr Anaesth 2006;16:1077-1079.

14. Driesson J. Neuromuscular and mitochondrial disorders: what is relevant to the anaesthesiologist?. Curr Opin Anaesthesiol 2008;21:350-355.

15. Russel SH, Hirsch NP. Anaesthesia and myotonia. Br J Anaesth 1994;72:210-216.

16. Catena V, Del Monte DD, Rubini A, Guccione C, Ricagna F, Gangeri $\mathrm{G}$, et al. Anesthesia and myotonic dystrophy (Steinert's syndrome). The role of intravenous anesthesia with propofol, cis-atracurium, and remifentanil. A case report. Minerva Anestesiol 2007;73:475479 .

17. Gutmann L, Phillips LH. Paramyotonia congenita. Seminarsm Neurology 1991;11:249-25. 